doi:10.5937/jaes14-10907

Paper number: 14(2016)4, 375, 233 - 238

\title{
CONCEPT OF INTELLIGENT LOGISTIC FOR AUTOMOTIVE INDUSTRY
}

\author{
Branislav Mičieta \\ University of Zilina, Faculty of mechanical engineering, Slovakia; \\ Jozef Herčko \\ University of Zilina, Faculty of mechanical engineering, Slovakia; \\ Milan Botka \\ Central European Institute of Technology, Slovakia; \\ Nenad Zrnić \\ University of Belgrade, Faculty of mechanical engineering, Serbia;
}

This paper describe concept of intelligent logistic for automotive industry created with value stream mapping. Automotive industry has been facing big impact of economic crisis in last years. European Commission prepared initiative to improve use of technology in automotive industry called Factories of the Future. This concept is using fourteen interrelated technology pillars to reach this goal. Application of this concept into automotive industry offer for company opportunity to be factory of the future with high level of competitiveness advantage.

Keywords: intelligent logistic concept, value stream mapping, automotive industry

\section{INTRODUCTION}

The automotive industry is one of the key factors which affect to the world economy. In addition to the direct impact of the financial aspects of the automotive industry directly or indirectly impact on employment, which the industry among Europe a key employer. Its link to the supply lines of the automotive industry in 2012, produces more than $10 \%$ of employment in the European Union [18]. The industry and many other industries in the past, face the economic crisis. The most visible impact of the crisis was the fall in production of vehicles in the world, where production fell year-on all types of motor vehicles in 2009 fell by almost $15 \%$ compared to 2008 (Table 1). The biggest decline in production volume in Europe in 2009 recorded decreasing by more than $27 \%$, and even in America by nearly 35\%. Significant impact on production was in Africa but, given the overall share of world production of less than $1 \%$, it can be considered negligible.

Table 1: Production of vehicles in regions [16]

\begin{tabular}{|c|c|c|c|c|c|c|c|c|}
\hline \multirow{2}{*}{ Year } & \multicolumn{2}{|c|}{ Europe } & \multicolumn{2}{c|}{ America } & \multicolumn{2}{c|}{ Asia + Oceania } & \multicolumn{2}{|c|}{ Africa } \\
\cline { 2 - 9 } & $\begin{array}{c}\text { Num. of } \\
\text { vehicles }\end{array}$ & $\begin{array}{c}\mathrm{Y} / \mathrm{Y} \\
\text { change }\end{array}$ & $\begin{array}{c}\text { Num. of } \\
\text { vehicles }\end{array}$ & $\begin{array}{c}\mathrm{Y} / \mathrm{Y} \\
\text { change }\end{array}$ & $\begin{array}{c}\text { Num. of } \\
\text { vehicles }\end{array}$ & $\begin{array}{c}Y / Y \\
\text { change }\end{array}$ & $\begin{array}{c}\text { Num. of } \\
\text { vehicles }\end{array}$ & $\begin{array}{c}\mathrm{Y} / \mathrm{Y} \\
\text { change }\end{array}$ \\
\hline 2007 & 22852578 & - & 19154059 & - & 30714858 & - & 544566 & - \\
\hline 2008 & 21770785 & $-4,97 \%$ & 16916515 & $-13,23 \%$ & 31256384 & $1,73 \%$ & 582847 & $6,57 \%$ \\
\hline 2009 & 17057293 & $-27,63 \%$ & 12531426 & $-34,99 \%$ & 31760155 & $1,59 \%$ & 413451 & $-40,97 \%$ \\
\hline 2010 & 19794758 & $13,83 \%$ & 16343430 & $23,32 \%$ & 40930255 & $22,40 \%$ & 515076 & $19,73 \%$ \\
\hline 2011 & 20954156 & $5,53 \%$ & 17793809 & $8,15 \%$ & 40576318 & $-0,87 \%$ & 556637 & $7,47 \%$ \\
\hline 2012 & 19863709 & $-5,49 \%$ & 20089597 & $11,43 \%$ & 43696469 & $7,14 \%$ & 586396 & $5,07 \%$ \\
\hline 2013 & 19789533 & $-0,37 \%$ & 21128805 & $4,92 \%$ & 45799146 & $4,59 \%$ & 636519 & $7,87 \%$ \\
\hline
\end{tabular}


European Commission led by J. M. Barroso in November 2008 prepared A European Economic Recovery Plan. It is a direct reaction of the European Commission on the situation after the crisis. A European Economic Recovery Plan with a view to maximize its benefits is focused on four areas - people, business, infrastructure and energy and research and innovation.

Within these areas it has been defined together 10 key actions aimed at fulfilling the message of the Plan. Key actions for industry growth was action - design of clean technologies for automotive and construction industry. Its objective is to support innovation in the construction and automotive industries, which in recent years experienced the most intense effects of crisis. As part of this action, proposed the creation of three major partnerships on the basis of a public-private partnership: with focus on automotive industry European green cars initiative; with focus on construction industry European energy-efficient buildings initiative; with focus on all industries initiative targeted to increase of use of technology in industry Factories of the Future initiative) [03]. The introduction of new technology in association with advanced industrial engineering has great potential to reduce these consequences, and also create the potential for growth of the sector in the long term [08][09][10].

\section{Methodology}

Created Intelligent Logistic for automotive industry has been created with use of Value Stream Mapping (VSM). VSM is different than conventional recording techniques, as it captures the information at individual stations about station cycle time, up time or utilization of resources, set-up time or change over time, work in process inventory, man power requirement and the information flow from raw material to finish goods [15]. A value stream is defined as all necessary actions, either value-added or non-value added activities that take place in manufacturing a single product or a family of products in the production flow. Both information and material flows are considered, beginning from raw materials and ending with finished goods in order to identify all types of waste and ultimately try to remove them [12][04]. VSM is a mapping tool that helps different business parties, i.e., management, suppliers, production, distributors and customers to map a production process or the whole supply chain network in order to locate wastes and their causes within the process value chain.

VSM creates maps of a production process to facilitate more thoughtful decisions and to improve the value stream of the process [06]. The first step is to select a particular product or a product family that uses the same resources as the target for improvement. The second step is to explore the current process, analyzing and identifying the system and its weak points in order to sketch a state map for the system. Creating the future state map or VSM is the next step. VSM is a representation of how the system should be after eliminating the wastes. VSM then becomes the basis for making the necessary changes to the system [12][17][13].

\section{Concept of intelligent logistic}

CEIT intelligent logistic concept is based on Value Stream Mapping methodology. Concept is based on 14 key pillars networked with flow relation. All parts of this concept is reflecting principles of Industry 4.0 [14]:

1) interoperability,

2) virtualization,

3) decentralization,

4) real-time capability,

5) service orientation,

6) modularity.

The current pressure on fast innovation in the factory means higher demands on logistic system design from the point of view of the laboriousness reduction, time and cost consumption for implementation of the entire designing process and increase of quality, complexity and information ability of outputs generated from the process [07]. Due to above mentioned reasons it is possible to summarize the basic designing requirements [07]:

1) quick draft of new solutions,

2) observance of the system approaches during design,

3) designing of logistics systems as a part of the digital factory concept,

4) interactive design of new logistics system,

5) a possibility of a running inspection and evaluation of proposed solution variants,

6) application of the optimization approaches in the individual stages of the logistics system draft,

7) suitable visualization and presentation of the designed outputs, 
8) a possibility of dynamic verification of proposed solution.

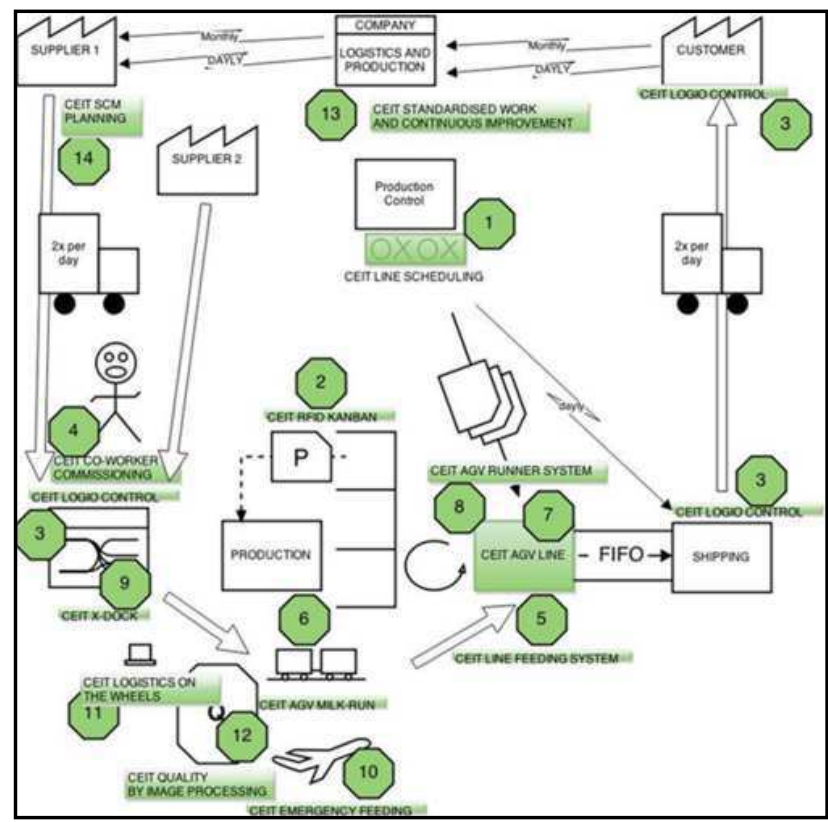

Figure 1: CEIT Intelligent logistic concept

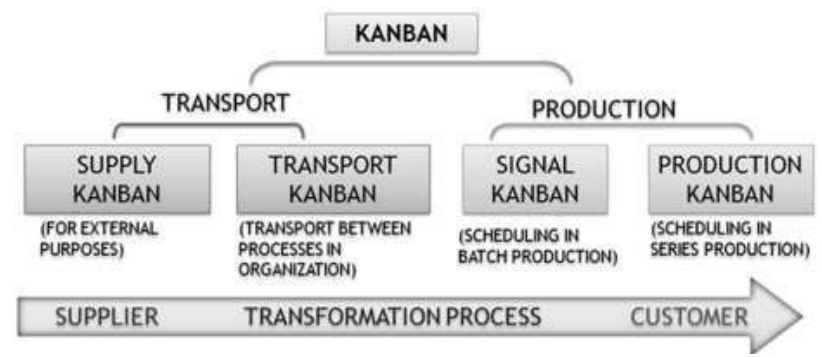

Figure 2: Distribution of Kanban systems by way of use [1]

This concept starts from production scheduling for production lines (pillar 1). It is for this reason that an intelligent system capable of a level of reconfigurability and adaptability that manufactures customs of the regular production started practicing as Toyota in the last century in the automotive industry. Manufacturing environment provides during the production period variable values, which must be extracted into the desired form. Sensors must ensure collection of required data, which are subsequently evaluated on the basis of stated variables. With the help of maintenance system in reconfigurable manufacturing system we can minimize the total costs which are related with downtime. [11] This schedule is the "engine" that drives the whole system of production according to customer requirements. Other circuits driven this engine are RFID Kanban (pillar 2) systems that allow only consume such material and intermediate products that were actually ordered by customers respectively were already paid. Factory don't spend money for material that is not used.

Delivering of material is based on Just-In-Time principle. When ordering materials to be consumed after the supplement is used LOGIO system (pillar 3) (Figure 3), which is used for uniform planning and logistical capacity ramps at the entrance and on the expedition, which will also reduce waiting times at the entrance to the company or waiting of trucks for loading.

After completion of purchased materials into a store and supermarkets are utilized intelligent robotic systems, cooperating with human (coworker commissioning (pillar 4)), designed to autonomously picking materials according to production and production schedule.

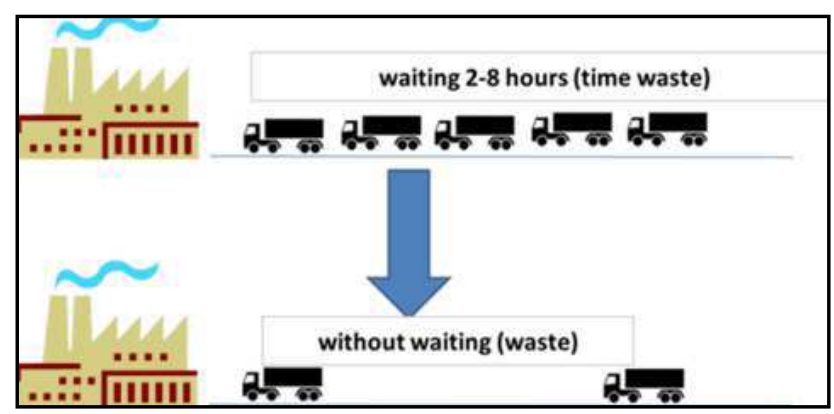

Figure 3: Elimination of time waste at inbound and outbound logistic

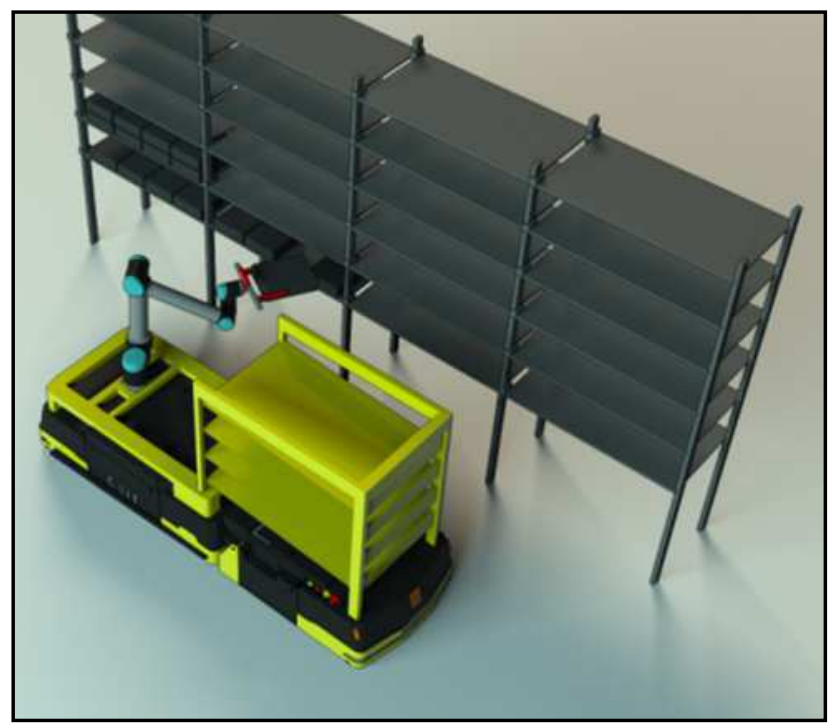

Figure 4: Picking order with AGV connected with co-worker

The basis for the solution of the CEIT is connection automated guided vehicle with co-worker robot. The modular connection provides the option of picking different materials in fully automatic mode. 
Thanks to the connection to the information systems by design picking is significantly faster, more efficiently and with certain materials safer. The material is placed at the point of consumption shooter system using line feeding system (pillar 5) (Figure 5).

Currently CEIT has two types used AGV - run under version and towing version. CEIT AGV systems has this advantages:

1) high speed - up to $2 \mathrm{~m} / \mathrm{s}$,

2) high towable weight - up to $3000 \mathrm{~kg}$,

3) brake energy regeneration,

4) wireless monitoring and control system,

5) automatic charging,

6) safety scanners,

7) towing and under-run version.

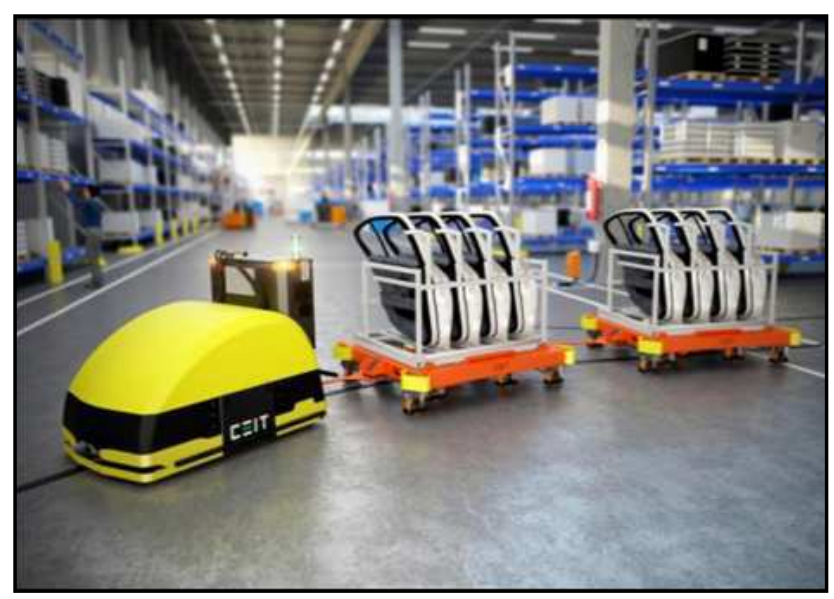

Figure 5: AGV system - towing version

Local consumption of the material is delivered intralogistics "milk-run AGV" (pillar 6) system consisting of AGV truck and about 3 wagons that can carry small (KLT), or large (GLT) packaging depending on the type of production. Where products are assembled on the line, each product is supported on the platform AGV and controlled these platforms form sol "AGV LINE" (pillar 7). In order to correct the imported goods to the right place and at the right time, used "runner system" (pillar 8) (Figure 6), which declined as supply just-in-time almost a second. If you slow down the line to slow down the supply so that there is printed works in the production and vice versa if the line speed up, speed up the supply in order to avoid downtime due to lack of parts. This timing is necessary to properly divide and picking material.

This is responsible for cross-dock (X-dock) (pil- $\operatorname{lar} 9)$. That the distribution of materials to places of consumption not work, they use the software efficiently and handling tools that ensure rapid de-palletization.

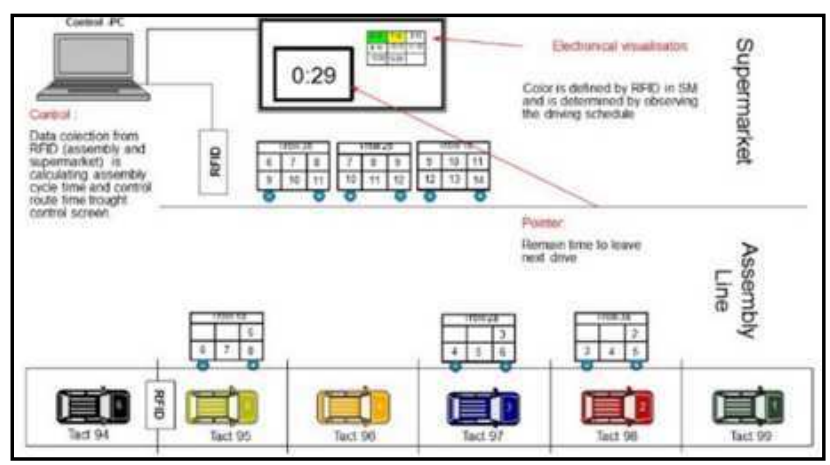

Figure 6: Scheme of supply using Runner in order to synch logistics and production with minimum of stocks

This may be a robot. By switching between manual and robotic de-palletization can be "logistics on wheels", a patent HARTTWALL Finnish company that guarantees a rapid disintegration of the palette to a series of KLT packages to the trolley (pillar 11). In the event that occurs in picking error, solve it quickly drone (emergency feeding (pillar 10)), which crosses the safe zone and adds material to two minutes in order to avoid loss of capacity for the assembly and the line did not stop, because minutes of downtime is estimated at $€ 10,000$. CEIT Intelligent Logistic is based on reduction of emergency feeding. This is realized on two main pillars - reduction of damages during processing and second on reduction of numbers of damaged part supplied by suppliers. First pillar is based on daily monitoring of damaged parts, finding reason of damage during processing and fix processes where part was damaged. Usually the bigger cost for emergency feeding is based on damaged parts supplied by supplier. The line can also stop because of poor quality or delivery of incorrectly labelled products to be checked before installation. For this type of control is used for video processing (image processing) (pillar 12) (Figure 7). The Intelligent Modular System of Quality Control (InMoSysQC) of parts is a prototype intelligent modular system. Its task is to control the quality of parts. Under the quality measurement on the sample we mean measurements of its characteristics, such as outside dimensions, weight, surface finish, and others [5]. One of the basic characteristics of modular equipment can perform easy, timesaving changes in the system, so that we may 
extension device with additional functions (in our case as an example, we can add other measuring devices at a lower level within one module or add a new module basal).

For continuous improvement of logistics and production processes is well organized so well established processes. Standardized Work (pillar $13)$, aimed at improving quality and productivity.

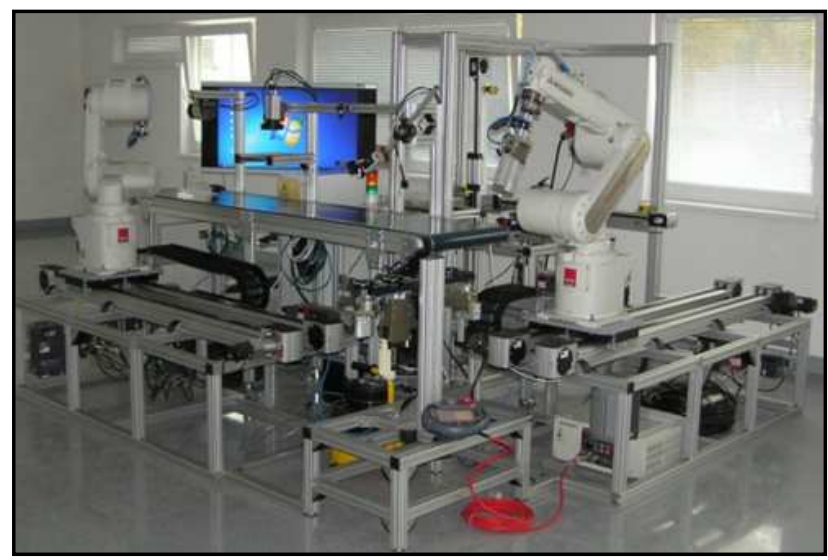

Figure 7: Prototype of InMoSysQC

This also applies to the process of supply, which can also be used Milk-run, but the external supply of the entire supply chain. Effective planning of supply (Supply Chain Management (pillar 14)) generates the biggest companies in the logistics savings (Figure 8 ).

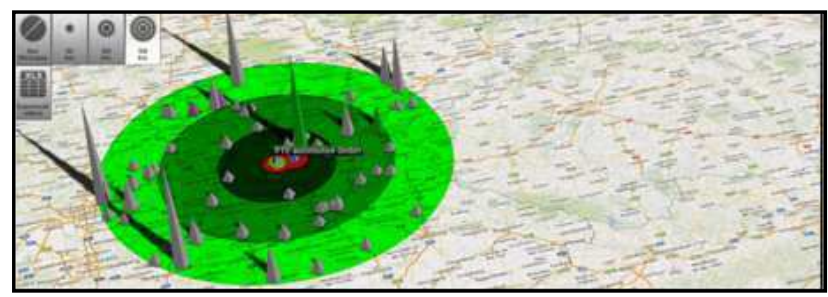

Figure 8: Visualization system for planning optimal logistics route

In general, the reasons why Milk-Run logistics has been widely employed are [02]:

1. Reduction in transportation costs due to consolidated transportation offsetting even the use of small lot transport.

2. Improvement of the assembly manufacturer's production line and greater accuracy of JIT goods delivery due to synchronization. Milk-Run logistics can provide consolidated collection of goods necessary to improve logistics procurement systems.

\section{CONCLUSION}

The aim of this paper is to introduce the individual components of CEIT Intelligent logistics concept. The basis of this concept are automated guided vehicles accompanied by other components of the system. Interconnection of components brings a wealth of technical and process innovation. It is these aspects directly in the reduced costs of internal logistics. For example, the introduction of automated logistics brings out significant time savings when transferring material even guarantee delivery of material to the production line at the right time and quantity without potential human errors. The creation and implementation of such a concept provides new opportunities for the introduction of smart manufacturing, which forms the basis for building Factories of the Future. At the same time innovations of existing solutions will bring further potential to reduce costs, increase productivity and competitiveness of factory. The introduction of this concept is directly dependent on the conditions and needs of the company, its modularity allows efficient logistics operation without the need of introducing the concept as it was presented.

\section{ACKNOWLEDGEMENT}

This paper is the part of research supported by project VEGA 1/0559/15.

\section{REFERENCES}

1) Binasova, V., Kubinec, L. (2015) Pull strategies in production management, ScienFIST. org, vol. 1, issue 2, pp. 6-13

2) Brar, G. S., Saini, G. (2011): Milk Run Logistics: Literature Review and Directions, Proceedings of the World Congress on Engineering, vol. I. pp. 797-801

3) Commission of the European Communities (2008): A European Economic Recovery Plan, Brussels: European Commission.

4) Esfandyari, A., Osman, M.R., Ismail, N., Tahriri, F. (2011): Application of value stream mapping using simulation to decrease production lead time: a Malaysian manufacturing case, International Journal of Industrial and Systems Engineering, Vol. 8, No. 2, pp. 230-250

5) Gregor, M., Hercko, J., Grznar, P. (2015): The Factory of the Future Production System Research, Proceedings of 21st International Conference on Automation and 
Computing (ICAC), pp. 254-259, DOI: 10.1109/IConAC.2015.7313998

6) McDonald, T., Van Aken, E.M., Rentes, A.F. (2010): Utilizing simulation to enhance value stream mapping: a manufacturing case application, International Journal of Logistics: Research and Applications, Vol. 5, No. 2, pp. 213-232, DOI: 10.1080/13675560210148696

7) Krajcovic, M., Stefanik, A., Dulina, L. (2016): Logistics processes and systems design using computer simulation, Communications: scientific letters of the University of Zilina, vol. 18 , no. $1 \mathrm{~A}$, pp. 87-94

8) Micieta, B., Binasova, V., Haluska, M. (2014): Advanced industrial engineering in next generation of manufacturing systems, Journal of Mechanics Engineering and Automation, Vol. 4, no. 4, pp. 311-317

9) Micieta, B., Binasova, V., Haluska, M. (2015): The approaches of advanced industrial engineering in energy efficient manufacturing, MM science journal, December 2015, pp. 778-784

10) Micieta, B., Binasova, V., Haluska, M. (2014): The approaches of advanced industrial engineering in next generation manufacturing systems, Communications: scientific letters of the University of Zilina, Vol. 16, no. 3A, pp. 101-105

11) Rakyta, M., Fusko, M., Haluska, M., Grznar, P. (2016): Maintenance support system for reconfigurable manufacturing systems, Proceedings of 26th DAAAM International Symposium on Intelligent Manufacturing and Automation, DAAAM 2015, pp. 1102-1108, DOI:10.2507/26th.daaam.proceedings. 155

12) Rother, M., Shook, J. (2003) Learning to See: Value Stream Mapping to Add Value and Eliminate MUDA. Brookline: Lean Enterprise Institute.

13) Sabaghi, M., Rostamzadeh, R., Mascle, Ch. (2015): Kanban and value stream mapping analysis in lean manufacturing philosophy via simulation: a plastic fabrication (case study), International Journal Services and Operations Management, vol. 20, No. 1, pp. 118-140, DOI: 10.1504/IJSOM.2015.065977
14) Saldivar, A.A.F., Li, Y., Chen, W.-N., Zhan, Z.-H., Zhang, J., Chen, L.Y. (2015): Industry 4.0 with cyber-physical integration: A design and manufacture perspective, Proceedings of 21st International Conference on Automation and Computing (ICAC), pp. 260-265, DOI: 10.1109/IConAC.2015.7313954

15) Singh, B., Garg, S.K., Sharma, S.K. (2011): Value stream mapping: literature review and implications for Indian industry, International Journal of Advanced Manufacturing Technology 53, pp. 799-809, DOI: 10.1007/s00170-010-2860-7

16) Slusna, L., Balog, M. (2015) Automobilovy priemysel na Slovensku a globalne hodnotove retazce, Bratislava: Slovenska inovacna a energeticka agentura.

17) Tapping, D., Luyster, T., Shuker, T. (2002) Value Stream Management, New York: Productivity Press

18) http://www.acea.be/statistics/tag/category/ employment-trends (retrieved on February 13rd, 2016

Paper sent to revision: 10.05.2015.

Paper ready for publication: 30.05.2016. 